\title{
Evolution of Civic Protest Movements \\ in Sub-Saharan Africa: \\ From Independence to the Present Day
}

\section{Lubow M. Sadovskaya}

Institute for African Studies, Russian Academy of Science

\author{
Naila Z. Fakhrutdinova \\ Institute for African Studies, Russian Academy of Science \\ Tatiana V. Kochanova \\ Institute for African Studies, Russian Academy of Science
}

\begin{abstract}
The study focuses on the civic protest movements (CPMs) in subSaharan Africa and analyzes three stages of their development, from the national liberation struggle of the 1950-1970s to establishment of national democratic institutions in the 1990s, to the 'third wave' of the activization coinciding with the beginning of the Arab Spring in 2011. Every period was characterized by different mobilization forms. Modern CPMs are driven mainly by urban youth who suffer from mass unemployment more than other age groups, while rural population remains relatively inert. Street mobilizations are led not by political figures or trade unionists (as it used to be during the period of anticolonial struggle), but by activists - representatives of the educated middle class and social network users who constantly keep in touch via Internet. They are fairly well-informed in all fields of life both in Africa and abroad, which gives them understanding of global inequality between African countries and advanced ones in terms of development of economy, medicine, education, as well as quality of living and life expectancy. Mobilization movements intend to demonstrate resentment towards the ruling circles' policies that are not aimed at improving people's lives and do not adhere to the principle of democratic rotation: rejuvenation of political elites and training alternative
\end{abstract}

Social Evolution \& History, Vol. 20 No. 2, September 2021 157-173

(C) 2021 'Uchitel' Publishing House DOI: 10.30884/seh/2021.02.07 
leaders. Protest movements are active in countries lacking public consensus, especially before and during presidential election campaigns. The article draws attention to the fact that, being predominantly political in nature, civic protest movements in this macrozone are becoming an important part of the political process and even result in changes of leadership (Senegal and Burkina Faso). Being inherently anti-system, they are organizationally unrelated with opposition parties, unions and their leaders. These movements are usually financed by Western foundations and international non-governmental organizations. One cannot exclude that these 'anti-system' movements will eventually transform into political parties, with their leaders turning into political actors.

Keywords: civic protest movements, sub-Saharan Africa, historical periods, street mobilization, conflict dynamics, electoral process, opposition parties

\section{INTRODUCTION}

Over the recent years, since the 2010s, the SSA became overtaken by vigorous protest actions that have attracted the interest of many researchers (Bouamama 2014; Branch and Mampilly 2015; Polet 2016; Strong 2018; Korotayev, Meshcherina, and Katkova 2019, etc.). The studies point out that these movements have substantially evolved from the struggle for independence in the $1950 \mathrm{~s}-1970 \mathrm{~s}$ and prodemocracy political protests of the 1990s to modern street mobilizations following 2010.

The subject of the evolution of African protest movements is scrutinized in scientific researches that focus on both previous and new modern forms of protest driven by the so-called 'street democracy' ('ruecratie'). New protest movements were so inclined to protesting in the streets and squares with demands as daring as resignation of acting president that during the revolution of 2014 young people of Burkina Faso coined a neologism 'ruecratie' that gained popularity throughout the African continent. At that time the pressure of the street became decisive (Bouquet 2017).

The researchers' interest to the civil resistance problem owes to the 'Arab spring' in North Africa as well as to emergence of 'yellow vests' and 'red vests' in a number of African countries (Egypt, Tunisia, Ivory Coast, Burkina Faso, and Central African Republic). These new movements were inspired by protest actions of the French 'yellow vests.'

It is worth noting that the first manifestations of the new wave of civic protest movements in SSA countries were caused by people's 
disillusionment with expected improvement of living conditions from the structural changes carried out by the governments, and with violations of basic democratic principles by the ruling class, which could be observed even before the Arab Spring. These movements emerged, for instance, in Burkina Faso after the assassination of journalist Norbert Zongo in 1998, in Guinea Conakry in 2006-2007, in Madagascar in 2009. In 2007-2008 and 2011 food price spikes resulted in increasing living costs and triggered social conflict manifested in strikes, protest matches and riots (Polet 2016).

Since 2005, Africa has witnessed over 100 massive anti-government protests in over 40 countries with the majority of them taking place after 2012 (Strong 2018: 9). Modern protest movements that intensified within the past few years (mostly since 2015) differ from those that took place in the 2000s. They can be characterized by predominance of political motives over economic ones. Mobilization movements intend to demonstrate resentment towards the ruling circles' policies that are not aimed at improving people's lives and adhering to the principle of democratic rotation. They are mainly supported by 'urban lower and middle classes' (Strong 2018), unemployed or underemployed youth. They are dissatisfied with their state's and government's policies, economic instability, corruption and the establishment hindering young professionals to rejuvenate the institutions of state power, which leaves youth only two alternatives: either sea or desert, either immigration or radicalization (Sadallah, Porret and Paolini 2018).

According to Jeff Goodwin and James Jasper, the emergence of protest movements is not an automatic response to objective frustrations, but is usually the result of perception of injustice and a significant contrast between the living conditions of citizens and their expectations (Goudwin and Jaspers 2003: 18).

But before turning to the analysis of modern protest movements in SSA, let us look into the past since historical retrospective allows a better understanding of their role and place in modern Africa.

\section{THREE STAGES OF THE ESTABLISHMENT OF PROTEST MOVEMENTS IN SSA}

Many researchers of African protest movements (Polet 2016; Branche and Mampilley 2015; Boubacar 2018; Dwyer and Zeilig 2012) conclude that national liberation movements of the 1950s-1970s were the first to attain mass popularity. For the anticolonial struggle to be successful, its leaders had to have a thorough understanding of living conditions not only in their native countries, but in whole Africa. It 
should be understood that, while leaders of modern African protest movements may freely make use of mass media available to common people, in those years such broad population coverage was impossible.

The newspapers and magazines originally published by missionaries played the role of opinion-givers. These print media attracted African intellectuals, including a number of such highly educated people as Kwame Nkrumah who had master's degrees in education and philosophy, social scientist and prominent poet Leopold Sedar Senghor, outstanding cultural figure, writer and poet Agostignho Neto, etc.

The struggle for independence produced a remarkable constellation of talented managers and theoreticians, some of them - Kwame Nkrumah, Leopold Sedar Senghor, Patrice Lumumba, Julius Nyerere, Agostignho Neto - later became heads of sovereign countries. They all were dedicated to ideals of freedom, self-sacrificing and had the common touch. These leaders knew how to mobilize common Africans and explain goals and methods of their struggle in laymen's language. They had charisma and talent for propaganda and kept to their word which was crucial for mass mobilization. Willing to give their lives for the idea of their nations' liberation from colonialism, many of them, such as Amilcar Cabral and Patrice Lumumba, became symbols of love of freedom, patriotism and courage. At that, these leaders were not populists, although their slogans sounded plain and simple for every African. Actually, they were devoted internationalists who hailed freedom, happiness and brotherhood of all nations. Kwame Nkrumah used to say that freedom conquered by Ghanaians would only become true if all Africa was decolonized (Bouamama 2014).

And this is what sets them apart from the modern CPM activists who focus on transnational exchanges levered by mainly the Internet and social networks that serve them as primary tools for 'notification', 'awareness creation' and 'mobilization'. Leaders fighting for high ideals were replaced by online activists, who even formed the socalled 'Africtivist' union. Nevertheless, the majority of them received university training (have education level $\mathrm{Bac}+5$ or higher) (Kalonji, Conve, and Bot 2016).

It is also worth paying attention to mobilization forms during the struggle for independence. They demonstrated considerable diversity in comparison with the modern ones and in most colonies included demonstrations, rallies, strikes, protest or civil disobedience actions and boycotting goods imported from the metropole. In a number of places the anticolonial struggle took the form of armed conflicts (the Malagasy Uprising in Madagascar in 1947-1948, the Mau Mau Uprising in Kenya in 1952-1956, riots in Cameroon in 1955 etc.). 
In the 1950s-1960s, the most massive protest movements were led by trade unions. The community principle was always relatable to Africans. Their esprit de corps was developed by communal lifestyle and traditional collective agricultural work. Among the particular characteristics of the formation of protest movements in the WestAfrican region is the fact that trade unionism had developed before the working class emerged. This discrepancy is largely related to colonial dependence and economic backwardness of the region, on the one hand, and growing influence of trade-unions in metropole, on the other. The level of organization of union protest demonstrations and the scales of strike action were largely dependent on personal qualities of the leaders. The most prominent among them, like Sékou Touré (Guinea), Sadou Diallo (Mali), Bassifou Gueye (Senegal), Djibo Bakary (Nigeria) etc., were able to make these movements highly political since they fought for social emancipation and national independence. In these leaders' programs the issue of struggle for national liberation considerably prevailed over the working class's economic demands. To a certain degree, they connected their union activities with party and political work.

It is important to note that ideology of the independent Africa's political leaders of the first generation evolved from general democratic and Pan-African slogans to the realization of the necessity to overcome backwardness and build a harmonious society (Bouamama 2014).

With the collapse of the colonial system the liberation struggle of African nations did not cease, instead entering a qualitatively new phase marked by the separation of class forces and political ones that used to show a united front and be bound together by the comprehension of their social interests. The new major challenge was to choose the way of further development.

Many SAA countries were taken over by a new generation of leaders of 'the second wave' - educated pragmatists. In the mid1980s, African countries were undergoing a severe economic crisis provoked by droughts and hunger. The circumstances were such that the ruling elites were forced to adopt the recommendations suggested by the World Bank and the International Monetary Fund and reorientate their countries' economies towards new programs of financial stabilization and economic restructuring. Their main purpose was liberalization of economic and political relations essential for restructuring of national economies and their adjustment to the demands of the international market. This cast a negative impact on the social sphere, such as education and healthcare. Restructuring programs involved privatization that led to layoffs and shutdown of social enter- 
prises. African authoritarian regimes were required to democratize political life and above all to introduce multi-party systems. In that period street mobilizations were motivated mostly by grim economic situation and at the same time accompanied by democratic demands to abolish one-party regimes. The pioneers of this 'new wave' of protest movements were Benin, Niger and Mali - the countries suffering the most dramatic economic degradation (Dobry 1992). It should be noted that in the early 1990s there were few protests but they gradually escalated, being promoted by new political coalitions composed of various social groups: trade unions, students, female associations etc. National conferences were the first events that showed the authorities' commitment to political liberalization. They were followed by gradual introduction of political, economic and union pluralism, arrangement of democratic (contested) elections, and drawing-up of new constitutions and their approval by referendums. These processes aiming at 'democratization of political life' (Guèye 2009: 8) were boosting 'consolidation' and 'euphoria' in the society. However, eventually by the end of the $1990 \mathrm{~s}$ - early 2000 s amidst the economic degradation that 'brought people to the streets' this euphoria began to evaporate. The first to protest openly were students, although their demonstrations lacked scale and their demands were limited to increasing scholarships, providing more places for applicants etc.

\section{'THIRD WAVE' OF COLLECTIVE MOBILIZATION}

The increasing number of CPMs in the SSA countries was to some extent connected with the events of the Arab Spring and may be regarded as one of the manifestations of its global echo (Korotayev, Shishkina, and Issaev 2016: 108). However, the causes of these protests are to be found above all within the African societies themselves. The political landscape in many SSA countries increasingly demonstrates the crisis of participatory democracy: national assemblies have turned into registration chambers for government acts and decrees. The judiciary is still usually dependent on the Executive. Corruption of political elites and their collusion with business circles are ubiquitous. Expensive election campaigns connected with vote buying and wealthy candidates being provided unfair advantages over qualified but less well-off ones are observed everywhere (Koter 2017). As a rule, the judiciary power still tends to depend on the executive one.

There is a lack of activity of political parties in the conditions of a multi-party system that does not justify itself. According to the authors of the research 'Africa Uprising: Popular Protest and Political 
Change', African countries have turned into 'democracies without choice' where citizens have formal voting power but there is little difference between parties (Branch and Mampilly 2015). In general, political parties do not represent public interests: on the contrary, they pursue their private ambitions or act for the benefit of coalitions that seek to have their share in the division of national wealth. Party elites do not neglect 'belly politics' (la politique du ventre) and clientelism. To this should be added the gerontocratic customs inherited from other generations, especially within the ruling parties, whose leadership was not really rejuvenated for years (Bayart 2006). As for the opposition, it comes from the same class against which it protests and, willingly or unwillingly, their aspiration to join the ranks of the disaffected is nothing more than a struggle against acting authorities for the power between fractions of the elite.

Furthermore, clientelism and ethnic preferences of the electorate do not propel democratic changes. The number of respondents who believe that politicians are forced to endorse their own circles more than the society as a whole varies from 5 per cent in Senegal to 50 per cent in Sierra Leone (Isakson and Bigsten 2017).

This issue clearly manifested itself in Nigeria in the 2019 preelection period. The election campaigns were held under such slogans as 'Not Too Young to Run!' and 'Ready to Run!' Their primary goal was to support young candidates to federal and local legislative assemblies. Apparently, the situation influenced the country's 75-yearold president Muhammadu Buhari who was constrained to sign a law reducing the age limit for presidential aspirants from 40 to 35 , and for gubernatorial candidates - from 35 to 30 .

The above-mentioned factors are partly responsible for the expansion of CPMs, especially in capital cities and depressed towns lying south from Sahara. They may be catalyzed by the aggravation of socio-demographic issues, especially in Western African countries suffering from dramatic population explosion. More and more young people migrate from rural areas to urban centers every year.

Urban youth is more affected by such socio-economic difficulties as unemployment, inequality and social injustice. The average situation in Africa is even worse. Across Africa as a whole, rapid demographic changes within the last 30 years account for the biggest and most fast-growing population of young people in the world: 70 per cent of the continent's overall population is under 30 (Strong 2018). According to Jack Goldstone's theory, as soon as the number of young people in society (persons under 25 years) exceeds 25 per cent, revo- 
lutions and uprisings begin (Goldstone 2006). Worse still, three out of five young workers in Africa lack the education level required for the participation in the labor market, which leads to long-term unemployment that reached its peak (48.1\%) in 2014 (Strong 2018).

At the same time, it should be taken into account that while the older generation (over 35) was unable to adjust to new information technologies, young people accepted progress as a given. Among other things, this new reality brought forth the erosion of information policy standards: as often as not, the approval of information by the audience becomes more valuable than truth, validity of facts and solving vital problems.

The smartphone revolution completed the widening of the gap with rural areas, where the influence of Muslim values is still quite strong; thus, political agitation is the fastest in agglomerations. Its advent was hastened by the process of young activists' mobilization via social networks. For these young people, tweets replaced propaganda leaflets. There are no names - only Internet logins, such as a clenched fist emerging from a forearm made of strands of a broom for the 'Balai Citoyen' movement, a hand waving a piece of red cardboard for 'Filimbi' etc. These signs help ordinary Internet users make sense of these movements. ${ }^{1}$

One of the accessories, distinguishing protest movements' activists in SSA countries, is a cap saying 'Amilcar Cabral.' These are all symbols used by new participants in the African political arena who claim to be champions of Pan-Africanism and successors to the most reputable African political leaders, such as Thomas Sankara and Patrice Lumumba, Amilcar Cabral and Kwame Nkrumah.

Modern movements based on social networks became 'not only an antistructure but a platform for the new protest policy, demonstrating a transition to a new type of opposition and political participation' (Smorgunov 2012: 159).

As, by contrast with parties and unions, CPMs are not institutional, any citizen, regardless his or her voting age, nationality or religion, can join them. They have neither membership cards nor fixed annual fees, but that does not prevent their members from raising and providing funds. They are not officially registered and communicate via social media and public platforms, using Facebook or Twitter (Rodger 2018). CPMs are led by young representatives of the urban culture rappers, painters, journalists and writers. Rap, dancing and graffiti allow these movements to attract young people who 'speak their language'. In the opinion of Senegalese political analyst Hamidou Anne, 
'rap brings a powerful protest message' (Anne 2018). Besides, it is performed in national languages. Growing popularity of Bobi Wine the Ugandian pop star and aspiring politician - reflects this new trend, when young people disappointed in the current situation follow politicians who promise changes.

These new 'African icons' are captivating with their speeches, with the way of doing things that differs significantly from the ruling political elite. Activists of protest movements returned citizens to the political space from which they were excluded, except for participation in elections.

It is important to emphasize that CPMs in most SSA countries have a populist component (activists speaking on behalf of grassroots; simple solutions to complex problems, etc.). They do not rely on legal democratic parliamentary procedures based upon political debates. Their distinctiveness lies in the fact that they match the traditional vertical party structure with a horizontal, network structure that uses modern communication technologies to bring together different segments of population, including representatives of the educated class who worry for their future.

\section{CPMS - A NEW FORM OF OPPOSITIONAL PARTICIPATION IN THE POLITICAL ACTIVITIES}

It is worth noting that sub-Saharan Africa with its numerous cultures, languages and religions, as well as abundant natural resources is a vivid example of diversity and therefore arouses immense interest from major global powers.

Considering the general picture of the global destabilization wave, one cannot rule out that Western nations will become interested in using protest movements to trigger political turmoil in order to manipulate the ruling class, especially in countries with recently discovered mineral deposits (Congo, Senegal, Chad, Mali, Guinea etc.). This may be facilitated by such common problems of countries of the macrozone as transnational terrorism, impetuous population growth, endemic poverty and insuperable corruption, as well as the most challenging problem - ethnic separation and inter-ethnic tension.

Among other things, the existence of ethnic and religious structures in African societies frequently impacts modern protest movements that are founded with due regard for these factors. For instance, the Ethiopian movements are predominantly based on ethnic strife between the country's two largest ethnic groups - the Oromo (34 \% of Ethiopian population) and the Amhara (27\%). One of the Amhara's 
slogans is 'The Economic and Political Power of the Oromo is Inadequate'. According to Amnesty International researcher Fisseha Tekle, the principle reasons for the emergence of protest movements are rooted in the country's history since the Oromo people were always considered 'alien' (Gardner 2018).

Prior to the impending presidential elections held on February $16^{\text {th }}$ of 2019, Nigeria - Africa's biggest oil producer - witnessed growth in activities of pro-religious civic protest movements 'Shi'a' and 'Biafra' a separatist group from Biafra. In their protest actions and demonstrations, they rally against corruption and financial crimes of the highest officials, and demand the release of their leaders - Ibrahim Zakzaky and his wife, as well as Nnamdi Kanu from Biafra.

As modern protest movements in West Africa are mostly political in nature, their role normally increases during presidential campaigns and consists in preventing constitutional changes that would allow increasing number of presidential mandates (more than two), and the re-election of the acting president, who had not carried out commitments given to the people before his inauguration.

\section{ANTI-SYSTEM MOVEMENTS AS A FACTOR OF SOCIAL TRANSFORMATION}

Many civil movements, like Y'en a marre in Senegal, Le balai citoyen in Burkina Faso, Filimbi and Lucha in the DRC, Togo Debout, Ça suffit in the Congo (Brazzaville), and La Croisade Niger in Niger, adopted for mobilization purposes the revolutionary and pan-African ideology of Thomas Sankara. Sankara's charisma still excites the minds of young people. His statement: 'Even if you kill a Sankara, thousands of Sankara will be born!' was widely used on social media and in speeches by activists of the Le balai citoyen protest movement during the popular uprising in Burkina Faso in 2014 (Degorce and Palé 2018). Sankara's ideas and actions remain attractive to 'angry' youth and to left-wing parties consisting of supporters of the former President Sankara, who was assassinated by Blaise Compaoré during the military coup in 1987. Demands for social justice became the main slogans in the days of the October Burkinabe uprising, which many researchers (Hagberg et al. 2015) qualified as a revolution carried out through mass mobilization (civil and military) in the name of social justice and the rule of law.

According to rapper Smokey - one of the founders of the Le balai citoyen movement, which is the undisputed leader of civil society organizations in Burkina Faso - the events of October 2014 were 'the 
second revolution, and the first popular revolution took place under Thomas Sankara in 1983-1987' (Thibault 2014).

The essence of another Y'en a marre movement, founded in 2011, was to search for horizontal connections that negate social hierarchy, there are no elders or leaders. It is built on the individual responsibility of each member, depending on its obligations, and is imbued with the ideology of solidarity.

The Y'en a marre strategy is developed for distant prospect. Since its establishment, it focuses main attention on monitoring the policies in the field of education, constitutional reforms and electoral processes. This anti-system movement, which acts 'against the government' ('contre pouvoir'), together with opposition political parties and public organizations, took an active part in large-scale street mobilizations against the third presidential term of Abdoulay Wade (Ly-Fall 2013). Y'en a marre called on its supporters to vote for his main rival, Macky Sall, who, thanks to their support, managed to win the second round.

Over time, the protest movements become more and more politicized. Y'en a marre is no exception. Its supporters, frustrated by the reality that does not meet expectations, criticize the Senegalese political system. They think it is "neo-colonial with a slanted justice and the Constitutional Council, subordinate to the government' (Marfaing and Kohnert 2019). Despite the President's promises during the election campaign to improve the lives of ordinary people, Senegal remains a poor country.

Since the 2019 presidential elections in Senegal, there has been a paradigm shift in the political, religious and civil spheres. This election opened up space for new anti-system candidates, such as Usman Sonko, ${ }^{2}$ who finished third out of five in terms of the number of votes. In addition, this youngest (46 years old) candidate won in Ziguinchor (the capital of the province of Casamance) and took second place in eight of the 21 departments of the country.

It is worth noting that the Y'en a marre movement sympathizes with non-system candidates; thus, it supports Ousmane Sonko and his party PASTEF (Senegalese Patriots for labor, ethics and brotherhood), founded in 2014. Its activists believe that over time, there may be a convergence of points of view and ideas between them, which will benefit primarily Senegalese citizens (Roger 2019).

Despite the fact that the Senegalese authorities accuse Ousmane Sonko of extremist statements, many young people consider him a Senegalese Sankara. In turn, Sonko highly appreciates the role of Y'en a marre in raising awareness and awakening the masses. Together 
with his party, he is developing a strategy, based on the latest program, for the period up to 2024 for the next regular presidential election. To this end, he announced the project 'Bokknaa 2.0' (J'adhère 2.0) and crowdfunding to raise 10 billion CFA francs for the implementation of the PASTEF political program (Sénégal: échauffourées à Dakar...N.d.).

Using the example of the Y'en a marre movement, we can conclude that young people currently prefer to choose new forms of interaction, such as creating startups, digital activism in an associative civil society. This means the emergence of a new type of discourse among young people, carried out by other methods and with other participants. Its goal is a democratic takeover of power. This form of transversality is absent in the usual political space (Diop 2020). At the same time, more radical methods remain in the youth environment - street protests. It is in this field that the interaction between Sonko, his party, Y'en a marre activists and other civil society organizations takes place.

This was confirmed by the protests that took place in Senegal from 3 to 8 March 2021. They were provoked by an attempt of the Senegalese authorities to put Ousmane Sonko in prison on a rape charge that had not yet been proven. The supporters of Sonko, activists of the J'en a marre movement, students, the unemployed, representatives of civil society opposed the authorities' intention to silence their main opponent. According to Fadel Barro, 'the authorities politicized the issue regarding the accusation of O. Sonko in rape' (Ndarinfo 2021).

Previously the PASTEF leader supported a peaceful rally banned by the authorities on July 14, 2019 against corruption in Senegal, initiated by opposition parties, Y'en a marre supporters and civil society associations. Despite the obstacles put up by the police (tear gas was used to disperse the crowd), the rally took place. The demonstrators chanted slogans: 'we are Senegalese. We have natural resources that do not belong to us, but to the President of the Republic and his family,' 'Macky is a dictator!', 'Macky is corruption!' etc.

The Senegalese opposition condemns corruption in the upper echelons of power. On June 2019, thirteen organizations, political parties and movements announced the creation of the 'Civil front'. ${ }^{3}$ It also included the Y'en a marre movement and Sonko's PASTEF party. The main goal of the Association is to establish 'transparency' in oil and gas contracts. Ousmane Sonko, like the Y'en a marre coordinators, believes that it is 'time for his generation to address issues of political governance and ethics' and that 'the driving force for change is youth' (Diop 2020). 
The example of Senegal shows that links between political parties and civil protest movements are expanding. This certainly helps to enrich the political environment and strengthen the support base of political parties that express sympathy for the protesters. What they have in common is that both are trying to involve as many young people as possible in the political space. They believe that the time has come for their generation to address issues of political governance.

Both Y'en a marre and PASTEF, for example, recognize themselves as defenders of Pan-Africanism. Their activists suggest a break with the political system that has existed since independence, which they consider neocolonial. In their opinion, it needs to be updated within the global discourse of transformations. To do this, they believe, it is worth referring to the work of Frantz Fanon 'Black Skin, White Masks' (Fanon 1952), in which the philosopher analyzed the consequences of colonialism on the cultural and social behavior of the masses.

However, civil movements, unlike political parties, do not seek to gain power. Moreover, the coordinators of the Le balai citoyen movement recently stated that they 'do not want to turn into a political party or even participate in the government.' They intend to remain active participants in civil society.

Most protest movements, including Y'en a marre, refuse to participate in parliamentary activities at this stage. They define their role as to involve citizens in the struggle for new value systems. Their ultimate goal is not only to create conditions for a complete political transformation, but also to promote social changes and development.

Another important trend is internationalization of modern civic protest movements. Their supporters constantly keep in touch with each other by moving from one country to another. Such meetings have already been held in Dakar, Ouagadougou and Kinshasa. During these meetings, their leaders arrange concerted actions aimed at increasing their influence over the electoral processes in the countries of the region in the months preceding presidential elections. The French historian Severine Awenengo Dalberto calls such activities 'political entrepreneurship' (Roger 2018).

Some Western political analysts (Polet 2016; Roger 2018) consider the leaders of civic movements to be potential political actors in the countries of West and Central Africa.

\section{CONCLUSION}

The analysis of evolution of protest movements in SSA countries shows that modern CPMs referred to as 'the third wave' (Polet 2016) 
are substantially different from the previous two waves (in the 1950s1970s and 1990s). They not only have more population coverage, but also stand out for their offensive character. For instance, in Burkina Faso the October events turned into revolution within a few days. However, despite the fact that the protest spread to most of the country and their participants managed to restore the rule of law - namely to achieve the resignation of Compaoré, - the protesters were caught in a vacuum. The reason was that they had neither a common leader, nor common ideology, nor an agenda agreed by participants from different political and social groups.

It is important to note that the majority of activists of modern protest movements are young people. This determines their motives and modus operandi. They call themselves the 'Android generation' and help everyone who does not see the point in political (in the classical sense of the word) struggle to act in a new way: participate in political debates without going through the 'filter' of political parties. They do not have life experience and ideology of previous generations, they are free from outdated stereotypes, more active and better informed by virtue of social networks, and that gives them the understanding of global inequality between African countries and developed ones in terms of economic development, quality of living and life expectancy.

Therefore, these movements set themselves the task of getting rid of the 'caste' of permanent politicians in order to make structural changes. Activists of protest movements and their supporters have a much deeper vision of the transformation of society and governance structures than political parties, and they demand fundamental changes in the country.

At the same time, the possibility of turning protest movements into political parties and their institutionalization cannot be excluded. For example, the Civil Alternative movement has already created a party in Benin, and the Filimbi movement in Congo-Kinshasa unites political associations and parties in the civil front (Banega 2016). But we cannot rule out future cooperation of the CPMs with individual opposition parties, in particular, with those that have developed programs for the development of the country, and not general words about democracy.

It will be difficult for the state to control and suppress these social movements, which represent real strength compared to the weak actions of political parties. Moreover, their transnationalization, supported by social networks, weakens the power of repression. They inspire hope that no government can remain deaf to the demands of the population. 


\section{NOTES}

1 Y'en a marre ('Enough!') - Senegal, Le Balai citoyen ('The Civic Broom') - Burkina Faso, Fulimbi ('The Whistle'), Lucha ('The Struggle for Change') - Democratic Republic of Congo (DRC), Jeunes et forts ('Young and Strong') - Cameroon, Ras-le-bol ('Enough is Enough!') - Congo-Brazzaville, OT Jeunes de la Côte d'Ivoire ('The "Youth of the Ivory Coast" Working Group'), Fees must fall - Nigeria, Ethiopia etc., Occupy Nigeria, Shia ('The Shi'a') - Nigeria, Ça suffit ('That's Enough!'), C'est trop ('This is Too Much!'), Iyana ('Enough!') - Chad, La Croisade Niger - 'Crusade') - Niger.

${ }^{2}$ Usman Sonko was dismissed from public service for criticizing the government. In his book 'Oil and gas in Senegal. Chronicle of distribution', he accused M. Sall and his entourage of embezzling funds in the management of natural resources.

${ }^{3}$ The civil front demands to investigate corruption cases in connection with the transfer of two oil fields to British Petroleum, in which the President's brother Aliu Sall is involved.

\section{REFERENCES}

Bandgaps, R. 2016. Mobilisations citoyennes, répression et contre-révolution en Afrique. Revue Projet 351: 6-11. URL: https://www.cairn.info/revueprojet-2016-2-page-6.htm. Accessed April 5, 2020.

Bayart, J.-F. 2006. L'état en Afrique: la politique du ventre. Paris: Fayard.

Branch, A. and Mampilly, L. 2015. Africa Uprising: Popular Protest and Political Change. Chicago: Chicago Univesity Press.

Bouamama, S. 2014. Figure de la révolution africaine. De Kenyatta à Sankara. Paris, La Découverte, coll. "Zones".

Boubacar, S.B. 2018. Analyse. Vent de contestation et d'espoir en Afrique de l'Ouest. URL: https://www.courrierinternational.com/article/analyse-ventde-contestation-et-desnair-en-afrique-de-louest Accessed April 11, 2020.

Bouquet, Ch. 2017. Les villes africaines, lieux d'incubation des mouvements citoyens. Diploweb, March 17. URL: https://www.diploweb.com/Les-villesafricaines-lieux-d-incubation-des-mouvements-citoyens.html. Accessed October 30, 2018.

Degorce, A., and Palé, A. 2018. Performativité des chansons du Balai citoyen dans l'insurrection d'octobre 2014 au Burkina Faco. Cahier d'études africains 1 (229): 127-153.

Diop, O. L. 2020. An 6 De PASTEF: Ousmane Sonko et Cie sur les sentiers de 2024. Enquete+, January 6. URL: https://www.enqueteplus.com/content/ 6-de-pastef-ousmane-sonko-et-cie-sur-les-sentiers-de-2024. Accessed May 6, 2020.

Dobry, M. 1992. Sociologie des crises politiques. La dynamique des mobilisations multisectorielles. Paris: Press de Sciences Po. 
Dwyer, P., and Zeilig, L. 2012. African Struggles Today: Social Movements since Independence. Oxford University Press.

Fanon, F. 1952. Peau noire, masques blancs. Paris: Editions du Seuil.

Gardner, T. 2018. Freedom: The Mysterious Movement that Brought Ethiopia to a Standstill. The Guardian, March 13. URL: https://www.theguardian. com/global-development/2018/mar/13/freedom-oromo-activists-qeerrooethiopia-standstill.

Goldstone, J. 2006. Toward a Fourth Generation of Revolutionary Theory. Logos. Publishing House 5 (56): 58-103.

Goudwin, J., and Jaspers, M. (dir.). 2003. The Social Movements Reader: Cases and Concepts. Blackwell Publischers.

Gyèye, B. 2009. La démocratie en Afrique: succès et résistences. Pouvoirs 2 (129): 5-26.

Hagberg, S., Kibora, L., Ouattara, F., and Konkobo, A. 2015. Au coeur de la révolution burkinabé. Antropologie \& développement 42-43: 199-224.

Isakson, A.-S., Bigsten, A. 2017. Clientelism and Ethnic Divisions in African Countries. African Affairs 116 (465) October: 621-647. Doi: 10.11777/ 004208591774709.

Kalonji, C., Couve, F. and le Bot, J. 2016. Citoyenneté numérique: ce que l'Afrique prépare. CFI, November 16. URL: https:/www.cfi.fr/fr/actualites/citoyennete-numerique-ce-que-lafrique-prepare. Accessed February 20, 2020.

Korotayev, A. V., Meshcherina, K. V. and Katkova, V. E. 2019. The Echo of the Arab Spring in the Countries southern Sahara: The Experience of Qualitative Analysis. Aziya i Afrika segodnya 1: 17-24. Original in Russian (Коротаев А. В., Мещерина К. В., Каткова В. Е. Эхо «арабской весны» в странах Африки южнее Сахары: опыт количественного анализа. Азия и Африка сегодня 1: 17-24).

Korotayev, A. V., Shishkina, A. R., Issaev, L. M. 2016. Arab Spring as a Global Phase Transition Trigger. Polis. Political Studies 3: 108-122. Original in Russian (Коротаев А.В., Шишкина А.Р., Исаев Л.М. 2016. Арабская весна как триггер глобального фазового перехода. Полис. Политические исследования 3: 108-122).

Koter, D. 2017. Costly Electoral Campaigns and the Changing Composition and Quality of Parliament: Evidence from Benin. African Affairs 116 (465): 573-596.

Ly-Fall, F. 2013. De la démocratie participative au Sénégal. "Le Nouveau Contre Pouvoir du Sénégal: Quand le Hip Hop transforme le regard sur la participation citoyenne. URL: https://www.participation-et-democratie.fr/ systeme/files/fatima_ly-communication_journels_doctorales_le_14_dec_ 2013.pdf. Accessed May 2, 2020. 
Marfaing, L. and Kohnert, D. 2019. Les élections présidentielles de 2019 au Sénégal ou la lente ascension des nouvelles générations. Canadian Journal of African Studies / Revue canadienne des études africaines 53 (2): 355-366. DOI: 10.1080/00083968.2019.1634465. URL: https://www. tandfonline.com/action/showCitFormats?doi=10.1080\%2F00083968.2019 .1634465. Accessed: 02 may 2020.

Ndarinfo. 2021. Ousmane Sonko: "par A ou B au plus tard en 2024, le Sénégal sera débarassé de Macky SALL". Ndarinfo, August 14. URL: https:// www.ndarinfo.com/Ousmane-SONKO-par-A-ou-B-au-plus-tard-en-2024-leSenegal-sera-debarrasse-de-Macky-SALL_a32090.html. Accessed August 26082021.

Polet, F. 2016. Afrique subsaharienne: entre révoltes populaires et restaurations autoritaires. État des résistances dans le Sud - Afrique. URL: https://www.cetri.be/Afrique-subsaharienne-entre?lang=fr. Accessed December 10, 2018.

Roger, B. 2018. Mouvements citoyens africains: qui sont ces jeunes leaders qui font du bruit? URL: https://www.jeuneafrique.com/228009/mouvements-citoyens-africains-qui-sont-ces-jeunes-leaders-qui-font-du-bruit/. Accessed September 20, 2020.

Roger, B. 2019. Présidentielle au Sénégal - Fadel Barro: Le seul candidat de "Y'en a marre". URL: https/www.jeuneafrique.com/733804/politique/presidentielle-au-senegal-fadel-barro-le-seul-candidat-de-y-en-a-marre-cesontles-senegalais/. Accessed October 19, 2020.

Sadallah, F., Porret, H., and Paolini, E. 2018. Au Sénégal. Y'en a marre préfère la rue à l'Assemblée. URL: https://www.france.24com/fr/20180123genegal-y-a-marre-rue-assamblee-politique-jeunes-macky-sall. Accessed January 20, 2019.

N.d.Sénégal: échauffourées à Dakar lors d'une manifestation anti-corruption interdite. URL: https://www.africaradio.com/news/senegal-echauffoureesa-dakar-lors-d-une-manifestation-anti-corruption-interdite-152142. Accessed May 5, 2020.

Smorgunov, L. V. 2012. Political "between": the Phenomenon of Liminality in Contemporary Politics. Polis. Political Studies 5: 159-169. Original in Russian (Сморгунов, Л. В. Политическое «между»: феномен лиминальности в современной политике / Полис. Политические исследования 5: 159-169).

Strong, K. 2018. Do African Lives Matter to Black Lives Matter? Youth Uprising and the Borders of Solidarity. Urban Education 1 (53), issue 2. February.

Thibault, G. 2014. Burkina Faso: Une Révolution Express. RFI, December 23. URL: https://www.rfi.fr/afrique/20141223-burkina-faso-une-revolutionexpress. Accessed January 9, 2019. 